\title{
PELATIHAN PEMBUATAN KEJU LUNAK ALAMI DAN PRODUK OLAHANNYA BAGI PETERNAK SAPI DI DESA PENGGING KECAMATAN BANYUDONO BOYOLALI
}

\author{
Indah Riwayati $^{{ }^{*}}$, Indah Hartati ${ }^{2}$, Harianingsih ${ }^{3}$ \\ ${ }^{1}$ Jurusan Teknik Kimia, Fakultas Teknik, Universitas Wahid Hasyim \\ Jl. Menoreh Tengah X/22, Sampangan, Semarang 50236 \\ ${ }^{2}$ Jurusan Teknik Kimia, Fakultas Teknik, Universitas Wahid Hasyim \\ Jl. Menoreh Tengah X/22, Sampangan, Semarang 50236 \\ ${ }^{3}$ Jurusan Teknik Kimia, Fakultas Teknik, Universitas Wahid Hasyim \\ Jl. Menoreh Tengah X/22, Sampangan, Semarang 50236 \\ "Email: indahriwayati@unwahas.ac.id
}

\begin{abstract}
Abstrak
Kabupaten Boyolali mempunyai berbagai macam potensi yang dapat dikembangkan untuk meningkatkan kesejahteraan masyarakatnya. Salah satu potensi yang cukup besar adalah jumlah ternak sapi perah yang cukup besar. Selama ini susu sapi yang dihasilkan di setor ke pabrik pengolahan susu untuk dijadikan susu olahan seperti susu pasteurisasi dan susu bubuk. Susu sapi perlu diolah menjadi makanan dengan nilai yang lebih tinggi dan tahan lama untuk mengatasi masalah penyimpanan produksi yang berlebih. Salah satu produk tersebut adalah keju lunak alami dan makanan olahannya. Keju lunak berbahan susu sapi dan getah buah pepaya. Bahan-bahannya mudah diperoleh, tersedia banyak dan harga yang relatif murah. Keju lunak dapat diolah lebih lanjut menjadi pepes, kerupuk atau makanan yang lain. Kegiatan ini mempunyai tujuan memberikan pengetahuan dan ketrampilan untuk membuat produk diversifikasi susu yaitu keju lunak alami dan olahannya. Makanan berbahan susu ini diharapkan dapat menjadi komoditas unggulan daerah tersebut melalui peningkatan kegiatan ekonomi produksi dan distribusi.
\end{abstract}

Kata kunci: keju, pepaya, susu, sapi,

\section{PENDAHULUAN}

Boyolali merupakan salah satu kabupaten yang terletak di propinsi Jawa Tengah. Nama Boyolali berasal dari kata dari bahasa Jawa "bayalali" yang artinya: lupa bahaya/marabahaya. Kabupaten ini terbentang sepanjang $49 \mathrm{~km}$ dari barat-timur, sedangkan dari arah utara-selatan sepanjang $54 \mathrm{~km}$. Sebagian besar wilayah terdiri dari dataran rendah serta sedikit perbukitan yang tidak begitu terjal. Kabupaten Boyolali terdiri atas 19 kecamatan dan 267 desa/kelurahan. Kecamatan di Boyolali terdiri Kecamatan Ampel, Andong, Banyudono, Boyolali, Cepogo, Juwangi, Karanggede, Kemusu, Klego, Mojosongo, Musuk, Ngemplak, Nogosari, Sambi, Sawit, Selo, Simo, Teras dan Kecamatan Wonosegoro. Terdapat dua gunung di wilayah Boyolali. Hal ini menyebabkan daerah Boyolali sangat subur dan menjadi salah satu lumbung pangan Jawa Tengah serta mempunyai potensi yang cukup besar dalam bidang pertanian dan peternakan. Potensi peternakan Boyolali terbesar seJawa tengah dengan hasilnya berupa susu dan daging sapi. Peternak sapi perah umumnya berada di wilayah selatan dan dataran tinggi yang mempunyai udara sejuk. Jenis sapi yang dipelihara berasal dari daerah sub-tropis Australia. Salah satu wilayah yang banyak peternak sapi perah adalah di desa pengging kecamatan Banyudono.

Susu sapi biasanya dijual ke pengepul untuk disetorkan ke pabrik pengolahan susu dengan harga Rp. 4000-5000 per liter. Harga jual susu sapi ditingkat peternak yang relatif rendah tersebut hampir tidak dapat menutup biaya pakan sapi. Oleh karena itu diperlukan suatu usaha untuk mengubah susu sapi segar menjadi produk dengan nilai jual yang lebih tinggi. Salah satu produk olahan susu segar adalah keju. Pembuatan keju melalui pemisahan komponen padatan dan cairan yang ada di susu segar melalui proses penggumpalan dengan bantuan enzim protease. Sumber enzim protease yang banyak dipergunakan untuk pembuatan keju adalah rennet yang berasal dari lambung anak sapi (Bornaz dkk., 2010). Penggunaan rennet sebagai koagulan pada proses pembuatan keju mengalami beberapa kendala, diantaranya ketersediaan yang terbatas serta harga yang relatif tinggi. Oleh karena 
itu banyak dilakukan upaya untuk memperoleh sumber proteinase yang lain. Beberapa tanaman dikenal sebagai sumber proteinase serta dapat menggumpalkan susu misalnya, Artichoke (Cynara scolymus), bedstraw (Galium aparine), cardoon (Cynara cardunculus), zucchini (Cucurbita pepo), pepaya (Carica papaya), ficin (ensim protease dari getah pohon tin / Ficus carica, Jelatang (Urtica dioica), buah nanas muda dan daun siwalan (Ridwan, 2006).

Salah satu daerah yang telah memanfaatkan susu sapi perah menjadi keju lunak adalah di daerah Kabupaten Enrekang Sulawesi Selatan. Keju lunak yang diproduksi didaerah tersebut menjadi makanan khas yang disebut Dangke. Dangke merupakan produk padat hasil penggumpalan susu sapi atau kerbau dengan bantuan enzim yang terdapat dalam getah pepaya (Rahman dan Rauf, 2013). Dangke enrekang dicetak dengan menggunakan tempurung kelapa dan dibungkus daun pisang serta dikenal luas sebagai pangan lokal unggulan Kabupaten Enrekang (Rahman, 2014). Kabupaten Boyolali mempunyai populasi ternak sapi yang cukup besar mencapai 86.363 ekor sapi perah dengan produksi susu sebesar 90-100 ribu liter per hari (BPS Pemkab Boyolali, 2015). Produk susu perah tersebut di tampung oleh koperasi yang kemudian dijual ke pabrik-pabrik susu olahan. Kegiatan ini bertujuan untuk memberikan ketrampilan dan pengetahuan kepada peternak tentang produk olahan susu yang relatif mudah cara pembuatannya serta menggunakan bahan-bahan yang tersedia di lingkungan sekitar.

\section{METODE}

Pelatihan dilakukan dengan metode ceramah (presentasi), diskusi dan praktek. Peserta yang mengikuti kegiatan sebanyak 10 orang terdiri dari ibu-ibu peternak sapi di desa Pengging Kecamatan Banyudono Kabupaten Boyolali. Pelatihan meliputi dua tahap kegiatan yaitu: 1. Pelatihan pembuatan keju lunak dari susu sapi, 2. Pelatihan pembuatan produk pangan dari olahan keju lunak berupa pepes keju dan kerupuk keju. Sebelum dilakukan praktek pembuatan produk-produk tersebut, para peserta diberikan sesi ceramah (presentasi) dan diskusi mengenai kedua hal tersebut.

\section{HASIL DAN PEMBAHASAN}

Kegiatan pelatihan dibagi menjadi dua tahap yaitu: pelatihan pembuatan keju lunak dengan bahandasar susu sapi, sedangkan yang kedua adalah pembuatan produk olahan dari bahan keju lunak tersebut berupa pepes dan kerupuk keju. Keju lunak dibuat dari bahan-bahan susu sapi, getah buah pepaya dan garam. Proses pembuatan keju lunak akan menghasilkan rendemen yang lebih tinggi jika getah pepaya dimasukan setelah susu dipanaskan terlebih dahulu dibandingkan dengan tanpa proses pemanasan. Umur simpan keju lunak akan dapat mencapai 6 bulan jika disimpan pada suhu $0-5^{\circ} \mathrm{C}$ dengan penambahan asam sorbat sebanyak $0,15 \%$ dan 21 hari tanpa asam sorbat. Pada suhu ruang $\left(30^{\circ} \mathrm{C}\right)$ umur simpan keju lunak mencapai 5 hari dengan penambahan asam sorbat $0,15 \%$ dan dua hari tanpa penambahan asam sorbat (Yesilva, 1993).

Selama ini para peternak sapi hanya memerah susu sapi dan menjualnya di koperasi, dari koperasi dijual ke produsen susu olahan. Proses tersebut di selalu berjalan lancar karena pada hari-hari tertentu misalnya saat liburan tidak ada penjualan, sedangkan produksi susu tetap. Hal tersebut menyebabkan terjadinya susu di peternak. Sementara peternak mengalami kesulitan untuk menyimpan susu karena sifatnya yang mudah rusak serta memerlukan tempat yang cukup besar karena komposisinya yang mengandung sebagian besar air. Oleh karena itu dengan memberikan pengetahuan cara membuat keju lunak dapat memberikan salah satu solusi pada para peternak dalam menyimpan susu yang tidak terserap di pasar. Disamping itu produk keju lunak ini dapat menjadi produk diversifikasi dari susu sapi dengan volume yang lebih kecil dibandingkan dengan susu sapi segar. Proses pembuatan keju lunak dari susu dapat dilihat seperti pada Gambar 1.

Tabel 1. Komposisi rata-rata susu sapi

\begin{tabular}{lc}
\hline Komponen & Prosentase $\mathbf{( \% )}$ \\
\hline Air & 87,29 \\
Abu & 0,71 \\
Protein & 3,42 \\
Laktosa & 4,92 \\
Lemak & 3,66 \\
\hline
\end{tabular}




\begin{tabular}{ll}
\hline $\begin{array}{l}\text { Jumlah zat } \\
\text { padat }\end{array}$ & 12,71 \\
\hline Sumber: Lampert (1975) &
\end{tabular}

Keju lunak yang telah terbentuk kemudian dipisahkan dari whey kemudian dapat dicetak menggunakan mangkok plastik kecil. Keju lunak ini dapat langsung dimakan atau diolah lebih lanjut menjadi makanan olahan yang lain. Pemanasan susu tidak terlalu tinggi sekitar $65-71^{\circ} \mathrm{C}$. Pemanasan yang terlalu tinggi akan dapat mendenaturasi $\beta$-lactoglobulin yang dapat beraksi dengan k-kasein. Hal ini akan menyebabkan k-kasein sulit dihidrolisis oleh enzim protease menjadi $\rho$-kasein yang merupakan protein yang terendapkan (Hatta, dkk., 2014). Susu merupakan cairan yang disekresikan oleh kelenjar mamae pada kelompok mamalia. Susu berfungsi bahan sumber makanan pada bayi mamalia. Komposisi susu sebagian besar terdiri dari air, protein, laktosa dan lemak. Komposisi susu sapi rata-rata dapat disajikan seperti pada tabel 1.

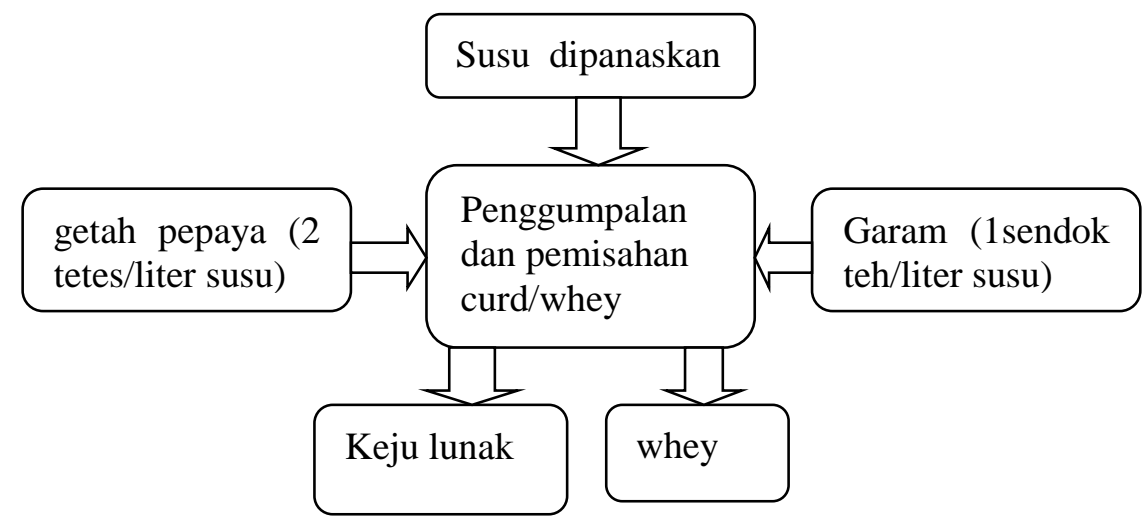

\section{Gambar 1. Proses pembuatan keju lunak}

Proses penggumpalan susu terjadi dengan bantuan getah buah pepaya (Carica papaya L). Getah ini banyak mengandung beberapa jenis enzim yang salah satunya bersifat proteolitik. Jenis enzim dan sifatnya dapat dilihat seperti pada Tabel 2 ..

Tabel 2. Sifat-sifat dan jenis enzim dalam getah pepaya

\begin{tabular}{llcc}
\hline \multicolumn{1}{c}{ Jenis enzim } & BM (gr/gmol) & Titik isoelektrik (pH) & Jumlah dalam getah (\%) \\
\hline Papain & 21000 & 8,75 & 10 \\
khimopapain & 36000 & 10,10 & 45 \\
Lisosim & 25000 & 10,50 & 20 \\
\hline Sumber: Yun
\end{tabular}

Sumber: Yuniwati dkk. (2008)

Enzim papain masuk dalam golongan protease sulhidril dengan sisi aktifnya berupa gugus sulhidril. Enzim ini bekerja optimum pada suhu $50-60^{\circ} \mathrm{C}$, pH 5-7 serta aktivitas sebesar 70-100 unit/gram. Kerja enzim papain dapat dihambat oleh senyawa oksidator, alkilator dan logam berat. Sedangkan aktivitasnya tergantung dari umur dan varietas pepaya yang dipergunakan (Yuniwati dkk., 2008). Penggunaan getah pepaya pada proses penggumpalan susu mempunyai batasan. Semakin banyak getah yang dipergunakan akan mengakibatkan keju yang dihasilkan berasa pahit serta berwarna kekuningan. Oleh karena itu penambahan getah pepaya harus optimum sehingga dapat menggumpalkan protein dan juga cita rasa yang cukup baik.

Pembuatan produk olahan keju berupa pepes dan kerupuk. Bahan untuk membuat pepes adalah keju, bawang merah, bawang putih, cabe merah, daun bawang dan daun pisang. Cara pembuatannya:

1. Keju lunak dihancurkan

2. Bawang merah, bawang putih, cabe merah dan daun bawang diiris-iris kecil 
3. Semua bahan dicampur dan diaduk sampai rata

4. Campuran bahan dibungkus dengan daun daun pisang kemudian dikukus

5. Setelah dikukus kemudian dibakar

Pepes keju dapat dimakan sebagai lauk yang mempunyai nilai gizi cukup tinggi.

Kerupuk keju dapat dijadikan camilan sehat bagi keluarga. Untuk membuat kerupuk keju membutuhkan bahan-bahan: tepung beras ketan, air, bawang putih, tepung tapioka, keju lunak, gula pasir, kaldu bubuk, garam, cabe rawit. Cara membuatnya adalah sebagai berikut:

1. Bawang putih, cabe rawit, keju lunak, kaldu bubuk, garam gula diblender sampai halus

2. Tuangkan campuran yang sudah diblender ke dalam panci, masak dengan api kecil, ditambah tepung beras ketan sebagian sambil diaduk sampai menggumpal, tuang dibaskom

3. Tambahkan tepung beras ketan dan tepung tapioka ulenai sampai tidak lengket, tuang ke loyang beralas plastik, kukus sampai matang

4. Setelah dingin masukan ke dalam kulkas agar keras

5. Setelah keras diris tipis-tipis dan dijemur sampai kering. Setelah kering dapat digoreng

Kerupuk ini dapat dikemas dalam kemasan plastik dan dijual sebagai oleh-oleh atau dijadikan camilan keluarga.

\section{KESIMPULAN}

Hasil susu sapi di desa Pengging kecamatan Banyudono Boyolali mempunyai potensi untuk menghasilkan keju lunak dan produk olahannya. Produk tersebut diharapkan dapat menjadi salah satu produk andalan wilayah tersebut untuk dijadikan komoditas oleh oleh yang dapat meningkatkan taraf ekonomi masyarakatnya.

\section{DAFTAR PUSTAKA}

Badan Pusat Statistik (BPS) Kabupaten Boyolali, (2015), Populasi Ternak Menurut Kecamatan dan Jenis Ternak di Kabupaten Boyolali, https://boyolalikab.bps.go.id/linkTableDinamis/view/id/62, diakses 26 Juli 2017, jam 12.18.

Bornaz, S., Guizani, N., Fellah, N., Sahli, A., Slama, M.B., Attia, H., (2010), Effect of Plant Originated Coagulants and Chymosin on Ovine Milk Coagulation, International Journal of Food Properties, 13, pp. 10-22

Hatta, W., Sudarwanto, M.B., Sudirman, I., Malaka, R., 2014, Survei Karakteristik Pengolahan dan Kualitas Produk Dangke Susu Sapi di Kabupaten Enrekang, Sulawesi Selatan, Jurnal Ilmu dan Teknologi Peternakan, Vol. 3 No. 3, 154-161.

Lampert, L.M., 1975. Modern Dairy Product. Chemical Publishing Company, Inc., New York

Rahman, S. Dan Rauf, A., (2013), IbM Kelompok Usaha Sapi Perah dan Pengolahan Dangke di Kabupaten Enrekang, Majalah Aplikasi Ipteks Ngayah, 4 (1), pp. 48-62

Rahman, S., (2014), Studi Pengembangan Dangke sebagai Pangan Lokal Unggulan dari Susu di Kabupaten Enrekang, Jurnal Aplikasi Teknologi Pangan, 3(2), pp. 41-45

Ridwan, M., (2006), Quality Function Deployment (QFD) untuk Peningkatan Kinerja Kualitas Produk Industri Kecil Khas Tradisional Dangke di Kabupaten Enrekang Sulawesi Selatan, Jurnal Pembangunan Desa, Vol.6, No. 3, pp. 175-182

Yesilva, A. 1993. Mempelajari Pengaruh Saat Koagulan, Penambahan Asam Sorbat dan Suhu Penyimpanan Terhadap Rendemen dan Mutu Dangke (Soft Cheese). Skripsi Jurusan Teknologi Industri Pertanian, IPB, Bogor.

Yuniwati, M., Yusran, Rahmadany, 2008, Pemanfaatan Enzim Papain sebagai Penggumpal dalam Pembuatan Keju, Prosiding Seminar Nasional Aplikasi Sains dan Teknologi, IST AKPRINd, Yogyakarta 